\title{
Financial Development and Economic Growth in the UAE: Empirical Assessment Using ARDL Approach to Co-integration
}

\author{
Husam-Aldin N. Al-Malkawi (Corresponding author) \\ Faculty of Economics and Administration \\ King Abdulaziz University, Saudi Arabia \\ P.O Box 80201 Zip Code: 21589 Jeddah \\ E-mail: h.almalkawi@gmail.com
}

Hazem A. Marashdeh

Faculty of Business, ALHOSN University

P. O. Box 38772, Abu Dhabi, United Arab Emirates

E-mail: h.marashdeh@alhosnu.ae

Naziruddin Abdullah

International Business School

Universiti Kuala Lumpur (UNiKL)

Jalan Sultan Ismail, Kuala Lumpur 50250, Malaysia

E-mail: nazirudin@hotmail.com

Received: March 7, 2012

doi:10.5539/ijef.v4n5p105

\author{
Accepted: March 16, 2012 \\ Published: May 1, 2012 \\ URL: http://dx.doi.org/10.5539/ijef.v4n5p105
}

\begin{abstract}
This paper empirically examines the relationship between financial development and economic growth in a small open economy of United Arab Emirates (UAE). Using time series data from 1974 to 2008, the study employs the autoregressive distributed lag (ARDL) approach to co-integration. The analysis is carried out using two indicators to measure the level of financial development. The first indicator is the financial depth or size of the financial intermediaries sector as measured by the monetization ratio (M2/GDP). The second indicator is the ratio of the credit provided to private sector by commercial banks as a percentage of the GDP (financial intermediation ratio). The results show a negative and statistically significant relationship between financial development, as measured by M2/GDP, and economic growth. The results also suggest a bi-directional causality between the two variables. Over all, the evidence supports neither the demand-following nor the supply-leading hypotheses for UAE.
\end{abstract}

Keywords: UAE, Financial development, Economic growth, ARDL, Co-integration

\section{Introduction}

Theoretically, financial development and economic growth are intimately related. That is to say, a well-developed financial system performs several critical functions to enhance the efficiency of intermediation by reducing information, transaction, and monitoring costs. More specifically, modern financial system promotes investment by identifying and funding good business opportunities, mobilizes savings, monitoring the performance of managers, enables the trading, hedging and diversification of risks, and facilitates the exchange of goods and services (Creane et al., 2004).

Economically, the above-mentioned functions will result not only in a more efficient allocation of resources but also a more rapid accumulation of physical and human capital and faster technological progress, all of which are expected to positively nourish economic growth.

Having said this, however, historically, a subject that relates financial development to economic growth was not so novel (Rousseau, 2003). In fact, it had taken a pretty good shape since the work of Bagehot (1873) before 
Schumpeter (1912) took a lead in showing that financial development promotes growth. However, Lucas (1988) opines that the importance of financial system in energizing economic growth is over-stressed. Apart from Schumpeter and Lucas, the third most influential study on the subject is by Robinson (1952). She asserts that "where enterprise leads, finance follows", which is at variance with the finding of the two above-cited authors.

Due to its importance from both researchers and policymakers' perspectives, the relationship between financial development and economic growth has been examined extensively. However, in the context of the high-income oil exporting economies of the Gulf Cooperation Council (GCC), in particular the United Arab Emirates (UAE), studies seemed to be somewhat scanty. Therefore, the primary objective of the present study is to fill this gap in the literature by providing evidence on the relationship between financial development and economic growth in one of the fast-growing emerging economy. The paper also aims to offer some policy implications for the decision-makers in UAE. In the most recent survey of the literature, Choong and Chan $(2011$, p. 2025) concluded that "it is of interest to all countries to gain insight into the finance-growth relationship" (Note 1).

This paper investigates empirically the long-run relationship and short-run dynamic linkages between financial development and economic growth in the UAE during the period 1974-2008. The study employs the autoregressive distributed lag (ARDL) approach to co-integration. The analysis is carried out using two indicators to measure the level of financial developments. The first indicator is the financial depth or size of the financial intermediaries sector and it is measured by broad money M2 as percentage of GDP. The second indicator is the ratio of the credit provided to private sector by commercial banks as a percentage of GDP. We included three control variables in our analysis. These variables are inflation rate (INF), trade openness (TO) and government expenditures (GOV).

To the best of our knowledge, this is the first study to utilize the ARDL approach for testing the finance -growth nexus in UAE. Most recent studies have indicated that ARDL approach is more preferable to other conventional approaches. The results show a statistically significant negative impact of financial development on economic growth.

The remainder of the paper proceeds as follows. Section 2 elaborates the theoretical background and previous research. Section 3 describes the data and methodology. The results are reported in Section 4. Section 5 concludes as well as provides policy implications of the paper. The final section outlines the potential limitations of this study.

\section{Theoretical Background and Previous Research: A Brief Overview}

The writings on the relationship between financial development and economic growth can be traced from the pioneering work of Schumpeter (1912), then Robinson (1952), McKinnon (1973), Shaw (1973), and, more recently, Lucas (1988), among others. To date, however, the relationship between financial development and economic growth is still a subject of great disagreement and controversy among researchers. This in turn has produced an immense academic literature, both theoretical and empirical. As a result, there exist a large number of works offering extensive survey of literature of this subject (see, for instance, Levine, 1997, 2004, Tsuru, 2000, Eschenbach, 2004, Demirgüç-Kunt and Levine, 2008, Acaravci, OzturkandAcaravci, 2009 and Choong and Chan, 2011). With a view to conserve space, we will only present a brief overview of the theoretical and empirical literature on finance-growth nexus in order to gain a better understanding of the issue.

The economic literature on the link between financial development and economic growth can be generally categorized into four different arguments. These are supply-leading (finance-led growth), demand-following (growth-led finance), feedback (bidirectional causality) and independent hypotheses (see, for example, Al-Yousif, 2002 and Majid, 2007). The first hypothesis, supply-leading, suggests that a well-functioning and well-developed financial intermediaries provides efficient allocation of resources through channeling the limited resources from surplus units to deficit units which in turn accelerate economic growth. "Financial development involves improvements in the (i) production of ex ante information about possible investments, (ii) monitoring of investments and implementation of corporate governance, (iii) trading, diversification, and management of risk, (iv) mobilization and pooling of savings, and (v) exchange of goods and services. Each of these financial functions may influence savings and investment decisions and hence economic growth" (Levine, 2004, p.6). Several prominent economists support the supply-leading hypothesis including Bagehot (1873), Schumpeter (1912), McKinnon (1973), Shaw (1973), Greenwood and Jovanovic (1990), and king and Levine (1993), among others.

On the other hand, the second hypothesis, demand-following, assumes that economic growth causes financial development i.e. "growth-led finance". In other words, as Robinson (1952) put it "where enterprise leads finance follows" (p. 86). From this perspective, the expansion in the real sector of the economy creates demand for new financial instruments and thereby the financial sector effectively responds to this demand. That is, economic growth leads to financial development. In addition to Robinson (1952), Gurley and Shaw (1967), Goldsmith (1969), Jung (1986) and Ireland (1994), for instance, support this hypothesis. 
The third argument on the finance-growth nexus is the feedback or "bidirectional causality" hypothesis. This view maintains that financial development and economic growth causes each other, that is, there is a two-way causality between financial development and economic growth. From this perspective, a better functioning financial sector can spur economic growth through enhancing technological changes and introducing innovative products and service, which in turn increases the demand for new financial services. As the financial intermediaries respond to these demands, these changes will propel economic growth (Majid, 2007). This hypothesis has received support from numerous theoretical and empirical studies including Patrick (1966), Demetriades and Hussein (1996), Luintel and Khan (1999), Greenwood and Smith (1997), Al-Yousif (2002) and Calderón and Liu (2003), among others.

Apart from the above-mentioned hypotheses, the forth view suggests that the relationship between financial development and economic growth is not important. This "independent" hypothesis, which was originally proposed by Robert Lucas (Nobel Laureate in economics) in 1988, argues that financial development and economic growth are not causally related. According to Lucas $(1988$, p.6) "economists badly overstress the role of financial factors in economic growth". Furthermore, in his influential survey of development economics, Nicholas Stern (1989) does not discuss the role of finance in the economic growth process. Stern also did not include it in his list of "omitted topics" that are worthy for future consideration (see also, Meier and Seers, 1984). More recently, Ram (1999, p.172) concluded that "...the predominant correlation between financial development and economic growth is negligible or weakly negative".

In fact, judging from the way economists across the Atlantic treating the topic, neither theoretical nor empirical consensus has yet been achieved. As Rousseau and Wachtel (2005, p.2) have aptly summarized: "while American authors (e.g., Levine and ourselves) often exhibit unbounded enthusiasm about the strength of the relationship, Europeans (Arestis, Demetriades and Temple, among others) are much more cautious and give more emphasis to the variability of the effects and the lack of robustness in some studies". From the cited works on finance-growth nexus, there is ample evidence to suggest that a model of economic development that is based on "one-size fits all" is almost non-existent.

As stated earlier, the literature on finance-growth relationship is vast and it is beyond the scope of this paper to present another review of the literature. However, we will present few studies that are either related to UAE context or employed the same methodology used in the present study (i.e., ARDL approach).

As far as the UAE economy is concerned, to the best of our knowledge, there is only one study that is fully devoted to examine the relationship between financial development and economic growth in the UAE. Using time series data from 1973 to 2003, Mosesov and Sahawneh (2005) examined the finance-growth nexus in UAE. The study employed standard OLS regression and used three variables to measure financial development, namely broad money to GDP (M2), credit to private sector to GDP (PSC) and domestic assets of resident banks to GDP (BDA). The paper also controlled for other variables that are believed to influence economic growth in the UAE, namely labor force growth, gross investment as percentage of GDP and oil prices. Inconsistent with their expectation, the coefficient on M2 is found to be negative and statistically significant at the 5\% level in their Regression 1 (without oil prices) and negative but not statistically different from zero in Regression 2 (with oil prices). The coefficients on the second financial development variable (PSC) are also found to be negative but not statistically significant. Similarly, the coefficients on the third financial development variable (BDA) are not statistically significant but positive. Mosesov and Sahawneh concluded that no positive evidence to suggest that financial development had influence the economic growth in the UAE. The control variables used in their study, however, are found to be positively and significantly related to economic growth in the UAE.

The above-mentioned study conducted by Mosesov and Sahawneh (2005) suffers from a serious methodological problem as it employed the standard OLS regressions. Such estimation method produces biased and incorrect estimates of the parameter coefficients and cannot capture the long-run dynamic relationship between financial development and economic growth. The drawback in Mosesov and Sahawneh's (2005) work has motivated the current study to overcome the limitations of their study by employing the appropriate econometric technique i.e., ARDL approach to co-integration in order to examine the finance-growth nexus in the UAE.

Meanwhile, as far as the methodology is concerned, Mohamed (2008) examined the short and long run relationship between financial development and economic growth in Sudan, one of the Middle East and North Africa (MENA) countries. Covering the period from 1970 to 2004, the study employed the ARDL modeling approach to co-integration. Specifically, he used two proxies for financial development. That is, the ratio of M3 to GDP (M3Y) and the credit provided by the commercial banks to private sector as a percentage of GDP (CBS). The result showed that financial development variables negatively affect real GDP. The coefficient on M3Y is found to be negative and statistically significant at the $1 \%$ level and the coefficient on CBS is also negative but insignificant. Mohamed 
attributed his finding to the inefficient allocation of resources by banks, the absence of proper investment climate, and to the poor quality of credit disposal of the banking sector in Sudan

Another study utilizes ARDL model of co-integration is conducted by Majid (2007). The study examined the short and long-run dynamics between financial development, inflation and economic growth during the post 1997 financial crisis in Thailand. The paper found a long-run equilibrium between economic growth, finance depth, inflation and share of investment. The study also documented that the common sources of economic progress/regress in Thailand is price stability and financial development. Specifically, this implies that in promoting the growth of economy, it is very important for the government to preserve price stability by maintaining a lower rate of inflation and enhancing the financial sectors both banking and stock market.

Seetanah (2008) used the ARDL model to investigate the dynamic empirical link between financial development and economic performance in a small island state of Mauritius. The results showed that financial development have been contributing to the output level of the economy in both the short and the long run. Using similar econometric approach, Kargbo and Adamu (2009) have arrived at the same conclusion for the case of Sierra Leone. The next section will elaborate on the data and the econometric modeling.

\section{Data, Model Specification and Methodology}

\subsection{Data}

The current study is based on time series data covering the period from 1974 to 2008 . The data are obtained from the country tables published by the International Financial Statistics (IFS) and the International Monetary Fund, World Economic Outlook Database.

\subsection{Model Specification}

The economic literature often suggests the following model of finance-growth nexus:

$$
Y=f(F D, C V)
$$

where $Y$ is the economic growth measured by the real gross domestic product (GDP) per capita growth (see Levine 1997), which is a function of $F D$ (set of financial development indicators) and $C V$ (other control variables believed to be linked to economic growth).

The financial development can be defined as "improvement in quantity, quality and efficiency of financial intermediary services (Calderón and Liu, 2003, p. 326). To measure the financial system development (FD), the literature has identified several indicators. Following Calderón and Liu (2003) and Al-Malkawi and Abdullah (2011), this paper will employ two proxies for financial development. The first proxy is the monetization ratio, or broad money supply (M2) to GDP (Note 2). We will refer to this proxy as M2.This measure has frequently been used by earlier research (see, for example, King and Levine, 1993, Levine, 1997, Gillman and Harris, 2004, Kemal, Abdul Qayyum and Hanif, 2007, and Odhiambo, 2008). This variable measures the financial depth or size of the financial intermediaries sector. It has been argued that the larger the size of the financial system the stronger it can contribute to economic activities by mobilizing savings and channeling them towards productive economic activities, and hence growth (see Levine, 1997). Based on the aforesaid discussion and consistent with previous research the M2 is expected to have positive relationship with economic growth.

The second proxy for financial development is the financial intermediation ratio, credit provided by financial intermediaries to the private sector as a percentage of GDP (Note 3). We will refer to this variable as DC. This proxy has been widely suggested in the literature (see, King and Levine, 1993, Levine, 1997, Andersen, 2003, and Kemal, Abdul Qayyum and Hanif, 2007, among others). This measure indicates the extent to which funds are channelled into private sector by financial intermediaries. This measure "is better than other measures of financial development used in the literature" and also "more directly linked to investment and growth" (Calderón and Liu, 2003, p. 326) (Note 4). Accordingly, and consistent with prior research, we expect the impact of the variable DC on economic growth to be positive.

As stated earlier, the purpose of this paper is to examine the relationship between financial development and economic growth. However, the standard literature has also identified other factors associated with economic growth, which is denoted here as $C V$ in Equation 1. Therefore, we included three control variables in our analysis. These variables are inflation rate (INF), trade openness (TO) calculated as import plus export as a ratio of GDP, and government expenditures (GOV).

\subsection{Methodology}

\subsubsection{ARDL Bound Testing Approach}

This study utilizes the newly proposed autoregressive distributed lag (ARDL) approach, developed and introduced by Pesaran and Shin (1995 and 1998), Pesaran et al. (1996), Pesaran (1997) and Pesaran et al. (2001). More of the recent 
studies indicate that ARDL approach is more preferable in estimating the co-integration relation to other methods like Engle and Granger (1987), Johansen (1988) and Gregory Hansen (1996). The ARDL approach to co-integration is a more reliable method than other conventional co-integration approaches and it is applicable irrespective of whether the underlying regressors are purely $I(0)$, purely $I(1)$ or mutually co-integrated. Unlike most of the conventional co-integration procedures, which are valid for large sample size, the ARDL approach is more robust and performs well for small sample sizes. By using the ARDL approach, one can estimate the long-run and the short-run components of the model simultaneously.

The existence of an error-correction term among a number of co-integrated variables implies that changes in the dependent variable are a function of both the level of disequilibrium in the co-integration relationship (represented by the ECM) and the changes in other explanatory variables. This tells us that any deviation from the long-run equilibrium will feed back into the changes in the dependent variable in order to force the movement towards the long-run equilibrium (Masih and Masih, 2002, p. 69).

To analyze the relationship between economic growth and financial development in UAE, an individual model for each financial development indicator will be employed based on the following two general models

$$
\begin{gathered}
G D P_{t}=a_{0}+a_{1} t_{t}+a_{2} D C_{t}+a_{3} G O V_{t}+a_{4} T O_{t}+a_{5} I N F_{t}+\varepsilon_{t} \\
G D P_{t}=a_{0}+a_{1} t_{t}+a_{2} M 2_{t}+a_{3} G O V_{t}+a_{4} T O_{t}+a_{5} I N F_{t}+\varepsilon_{t}
\end{gathered}
$$

In the first model (Equation 2), economic growth is represented by real GDP growth as a dependent variable, while the independent variables are domestic credit to private sector as a percentage of GDP (DC) (financial intermediation ratio), $G O V_{t}$ is a measure of government expenditure as a percentage of GDP, $T O_{t}$ is a measure for trade openness as a percentage of GDP, $I N F_{t}$ is a measure of inflation, $t_{t}$ is the time trend, and $\varepsilon_{t}$ is an error term. In the second model (Equation 3), with $M 2_{t}$ (i.e., M2 as a percentage of GDP) being the only exception, other variables remained unchanged.

Based on the above general models, the error correction representation of the ARDL model can be presented as follows:

Model 1: Economic growth and financial intermediation ratio (DC)

$$
\begin{aligned}
& \Delta G D P_{t}=a_{0}+\sum_{i=1}^{n} a_{1} \Delta G D P_{t-i}+\sum_{i=1}^{n} a_{2} \Delta \ln D C_{t-i}+\sum_{i=1}^{n} a_{3} \Delta \ln G O V_{t-i} \\
& +\sum_{i=1}^{n} a_{4} \Delta \ln T O_{t-i}+\sum_{i=1}^{n} a_{5} \ln I N F_{t-i}+\lambda_{1} G D P_{t-1}+\lambda_{2} \ln D C_{t-1}+\lambda_{3} \ln G O V_{t-1} \\
& +\lambda_{4} \ln T O_{t-1}+\lambda_{5} \ln I N F_{t-1}+\beta t+\varepsilon_{t}
\end{aligned}
$$

Model 2: Economic growth and monetization ratio (M2)

$$
\begin{aligned}
& \Delta G D P_{t}=\delta_{0}+\sum_{i=1}^{n} \delta_{1} \Delta G D P_{t-i}+\sum_{i=1}^{n} \delta_{2} \Delta \ln M 2_{t-i}+\sum_{i=1}^{n} \delta_{3} \Delta \ln G O V_{t-i} \\
& +\sum_{i=1}^{n} \delta_{4} \Delta \ln T O_{t-i}+\sum_{i=1}^{n} \delta_{5} \ln I N F_{t-i}+\alpha_{1} G D P_{t-1}+\alpha_{2} \ln M 2_{t-1}+\alpha_{3} \ln G O V_{t-1} \\
& +\alpha_{4} \ln T O_{t-1}+\alpha_{5} \ln I N F_{t-1}+\beta t+\varepsilon_{t}
\end{aligned}
$$

In the first model (Equation 4), the null hypothesis of "non-existence of the long-run relationship" defined by $\left(H_{0}: \lambda_{1}=\lambda_{2}=\lambda_{3}=\lambda_{4}=\lambda_{5}=0\right)$ and it is tested against the alternative hypothesis $\left(H_{0}: \lambda_{1} \neq \lambda_{2} \neq \lambda_{3} \neq \lambda_{4} \neq \lambda_{5} \neq 0\right.$ ). In the second model (Equation 5), the null hypothesis of "non-existence of the long-run relationship" is defined by $\left(H_{1}: \alpha_{1}=\alpha_{2}=\alpha_{3}=\alpha_{4}=\alpha_{5}=0\right)$ and it is tested against the alternative hypothesis $\left(H_{1}: \alpha_{1} \neq \alpha_{2} \neq \alpha_{3} \neq \alpha_{4} \neq \alpha_{5} \neq 0\right)$. These hypotheses are examined using the standard F-statistics. Two sets of asymptotic critical values are provided by Pesaran et al. (2001). The first set assumes that all variables are $I(0)$ while the second category assumes that all variables are $I(1)$. If the computed F-statistics is greater than the upper bound critical value, then we reject the null hypothesis of no co-integration and conclude that there exists steady state equilibrium between the variables. If the computed F-statistics is less than the lower bound critical value, then the null hypothesis of no co-integration cannot be rejected. If the computed F-statistics falls within the lower 
and upper bound critical values, then the result is inconclusive. In this case, following Kremers, Ericsson and Dolado (1992) the error correction term will be a useful way of establishing co-integration. The second step is to estimate the long-run coefficients of the same equation and the associated ARDL error coercion models.In order to determine the optimal lag-length incorporated into the model and select the ARDL model to be estimated, the study employs the Akaike Information Criteria (AIC).

\subsubsection{Vector Error Correction Model (VECM) Framework}

The following step is to construct a standard Granger causality test. The Granger causality approach says that $\mathrm{Y}$ is said to be granger-caused by $\mathrm{X}$ if $\mathrm{X}$ helps in predicting the value of $\mathrm{Y}$. In other words, the lagged values of $\mathrm{X}$ are statistically significant. The null hypothesis $H_{0}$ tested is that $\mathrm{X}$ does not granger-cause $\mathrm{Y}$ and $\mathrm{Y}$ does not granger-cause $\mathrm{X}$. The test will be augmented with a lagged error correction term when variables are co-integrated, and then estimated within a Vector Error Correction Model (VECM). This procedure is more attractive than the standard VAR because it permits temporary causality to emerge from firstly, the sum of the lagged differences of the explanatory differenced variable, and secondly, the coefficient of the error-correction term.

The conducting of this test helps to explore the short and long-run dynamic relationships between economic growth represented by the percentage of GDP per capita growth, and the financial development represented by the monetization ratio(M2) and the financial intermediation ratio (DC).Based on the theoretical background, if two variables, i.e. $y_{t}, x_{t}$, are co-integrated with each other, then the error correction term is required in testing Granger causality. At the same time, neglecting the error correction term (ECT) when testing for causality among co-integrated variables leads to serious biases due to filtering out low-frequency (long-run) information. The VECM is given by

$$
\Delta Y_{t}=a_{0}+\pi y_{t-1}+a_{1} \Delta y_{t-1}+a_{2} \Delta y_{t-2}+\ldots+a_{p-1} \Delta y_{t-p+1}+\varepsilon_{t}
$$

where $\Delta$ is a difference operator, $y_{t}$ a column- $n$ vector of endogenous variables, $a_{l}, \ldots, a_{p-l}$ are $(n \times n)$ matrices of coefficients, and $\varepsilon_{t}$ is a vector of normally and independently distributed error terms.

\section{Results and Discussion}

The results of the ARDL bound test are shown in Table 1. The calculated F-statistics for model 1 is less than the lower bound critical value. Based on this result the null hypothesis cannot be rejected, which suggests that there is no cointegration when using financial intermediation ratio (DC) as a financial indicator for economic growth. Based on this result the second step to estimate the long-run coefficients of the same equation and the associated ARDL error coercion models cannot be continued.

For ease of reference, we report the calculated F-statistics for the model 2, and it is 4.812, which is significant at $95 \%$ level. This result provides evidence for the existence of long-run relationship among economic growth represented by the real GDP, the financial development represented by monetization ration (M2), and also government expenditure, trade openness and inflation. This indicates that these variables have a long-run equilibrium, thereby having the tendency to move together in the long-run.

In the second stage, we estimate the long-run coefficients of the selected ARDL model using the variable (M2) as a financial indicator. The overall goodness of fit of the estimated equation, as shown in Table 2, is extremely high with $R^{2}=0.99$; the F-statistic measuring the joint significance of all regressors is statistically significant ( $p$-value $=.000$ ). Meanwhile, the diagnostic tests of the model show no serial correlation and no heteroscedasticity. The AIC lag specification is $\operatorname{ARDL}(1,1,0,0,1)$, where the numbers represent the lags for the variables which are listed in the same order. The long-run coefficient estimates are reported in Table 2.

The results show that the financial development indicator, as measured by M2 to GDP, has a significant negative impact on economic growth in the case of UAE. Similarly, the control variables namely, government expenditure, trade openness and inflation are found to have significant negative impact on economic growth (Note 5).

Although the result of the negative relationship between the financial development and economic growth reported in this study is inconsistent with general evidence in the empirical literature, it is not surprising in the case of UAE. A possible explanation for that, over our study period (1979-2008), the UAE financial system was still in the transition phase and needs to reach a certain level of development before it will be able to promote economic growth. In addition, as Al-Yousif (2002, p.147) suggested, this negative relationship between the two variables (i.e. monetization ratio and economic growth) can be attributed to the act of "business cycle rather than a representation of a long-run relationship. Also, according to him "due to the fact financial intermediaries operating in a weak regulatory environment combined with the expectation that government will bail out failing banks". This explanation is quite plausible for GCC countries in general and for the UAE in particular. 
Furthermore, the result obtained in this paper is consistent with Mosesov and Sahawneh (2005) who reported negative and significant relationship between financial development as measured by M2/GDP and economic growth in the UAE. In an earlier study, Ram (1999) did not support the view that financial development promotes economic growth. Using data for 95 individual countries including UAE, Ram found negligible or weakly negative correlation between financial development and economic growth. The coefficient of correlation between M2/GDP and GDP is found to be negative for UAE, but insignificant. Also, Gillman and Harris (2004) obtained negative and significant coefficient on M2/GDP for 13 transition countries. More recently, Mohamed (2008) reported similar result for Sudan.

Following the exploration of the long-run association between economic growth, monetization ratio (M2), with control variables namely; government expenditure, trade openness and inflation, we proceed to perform multivariate Granger-Causality test based on VECM. The core value of this test is to reveal the direction of causation among variables. Table 3 reports the results of causation among all variables. The results show that there are significant negative short-run dynamic bidirectional causations between the financial indicator (M2) and economic growth represented by GDP per capita growth.

The coefficient of the estimated error correction model (ECM) of the selected ARDL (when real GDP is considered as dependent variable) has the correct negative sign, which is highly significant at $1 \%$. This confirms the existence of long-run relationship between the two variables. Beside that it represents the speed of adjustment to restore equilibrium in the dynamic model following disturbance. The coefficient of the ECM is -0.2625 , suggesting that a deviation from the long-run equilibrium following a short-run shock is corrected by about $26 \%$ in less than a year.

\section{Conclusions and Policy Implications}

This paper empirically examines the relationship between financial development and economic growth in a small open economy of United Arab Emirates (UAE). Using time series data from 1974 to 2008, the study employs autoregressive distributed lag (ARDL) approach to co-integration. The analysis carried out using two indicators to measure the level of financial development. The first indicator is the financial depth or size of the financial intermediaries sector as measured by the monetization ratio (M2/GDP). The second indicator is the ratio of the credit provided to private sector by commercial banks as a percentage of the GDP (financial intermediation ratio). We included three control variables in our analysis. These variables are inflation rate (INF), trade openness (TO) and government expenditures (GOV).

To the best of our knowledge, this is the first study to utilize the ARDL approach for testing the finance -growth nexus in the UAE. Most recent studies have indicated that ARDL approach is more preferable to other conventional approaches.

The results show a negative and statistically significant relationship between financial development, as measured by M2/GDP, and economic growth. The results also suggest a bi-directional causality between the two variables. A possible explanation for that, over our study period (1979-2008), the UAE financial system was still in the transition phase and needs to reach a certain level of development before it will be able to promote economic growth. Moreover, as Al-Yousif (2002, p.147) suggested, this negative relationship between the two variables (i.e. monetization ratio and economic growth) can be attributed to the act of "business cycle rather than a representation of a long-run relationship. $\mathrm{He}$ also argued that it could be, "due to the fact financial intermediaries operating in a weak regulatory environment combined with the expectation that government will bail out failing banks". This explanation is quite plausible for GCC countries in general and for the UAE in particular.Over all, the evidence supports neither the demand-following nor the supply-leading hypotheses for UAE.

In responding to such inconclusive result between financial intermediaries and economic growth, a policy that is geared towards an extensive liberalization of the business and financial services is thought wise considering. This is being the case as UAE is getting more matured in terms of politics and economics, and is more exposed to unpredictable and robust world economy. While responsibility for promoting the liberalization of banking and financial services rested with the UAE Central Bank, the Ministry of International Trade and Industry, and Ministry of Finance are expected to promote other services and incentives, which in one way or the other is supportive of what is done by the Central Bank.

\section{Limitations of the Study}

The study is based on the data set that is constructed from the publications of the IFS and IMF. The reliability and accuracy of that data will therefore, affect the robustness of the results of the present study. All efforts have been made to ensure the accuracy of the data, but this potential data problem remains. 
Another limitation is related to the various proxy variables used. Although the proxy variables used in this study were defended empirically and theoretically, they remain proxies and may not perfectly represent the theoretical propositions. Once again, the proxy variable issue is a problem common to all empirical testing in finance-growth nexus, and more generally.

\section{References}

Acaravci, S. K., Ozturk, I., \& Acaravci, A. (2009). Financial Development and Economic Growth: Literature Survey and Empirical evidence from Sub-Saharan African Countries. South African Journal of Economic and Management Sciences, 12, 11-27.

Al-Malkawi, H. N., \& Abdullah, N. (2011). Finance-Growth Nexus: Evidence from a Panel of MENA Countries. International Research Journal of Finance and Economics, 63,129-139.

Al-Yousif, Y. K. (2002). Financial Development and Economic Growth: Another Look at the Evidence from Developing Countries. Review of Financial Economics, 11, 131-150.

Andersen, S. A. (2003). The Influence and Effects of Financial Development on Economic Growth: An Empirical Approach. Working Paper, No. 14, Chr. Michelsen Institute (Development Studies and Human Rights).

Bagehot, W. (1962). Lombard Street: A Description of the Money Market, Homewood, IL: Richard D. Irwin.

Calderón, C., \& Liu, L. (2003). The Direction of Causality Between Financial Development and Economic Growth. Journal of Development Economics, 72, 321-334. http://dx.doi.org/10.1016/S0304-3878(03)00079-8

Choong, C., \& Chan, S. (2011). Financial Development and Economic Growth: A Review. African Journal of Business Management, 5, 2017-2027.

Creane S., Goyal, R. A., Mobarak, M., \& Sab, R. (2004).Financial Development in the Middle East and North Africa, Working Paper No.WP/04/201, IMF, Washington DC.

Demetriades, P., \& Hussein, K. A. (1996). Does Financial Development Cause Economic Growth. Journal of Development Economies, 51, 387-411. http://dx.doi.org/10.1016/S0304-3878(96)00421-X

Demirgüc-Kunt, A., \& Levine, R. (2008).Finance, Financial Sector Policies, and Long-Run Growth. Policy Research, Working Paper, No. 4469. World Bank, Washington D.C.

Engle, F., \& Granger, C. W. J., (1987).Co-integration and Error Correction Representation, Estimation, and Testing. Econometrica, 55, 251-276. http://dx.doi.org/10.2307/1913236

Eschenbach, F. (2004). Finance and Growth: A Survey of Theoretical and Empirical, Tinbergen Institute Discussion Paper, No. TI 2004-039/2.

Gillman, M., \& Harris, M. N. (2004).Inflation, Financial Development and Growth in Transition Countries.Working Paper, No. 23/04, Department of Econometrics and Business Statistics, Monash University, Australia.

Goldsmith, R., W. (1969). Financial Structure and Development.Yale University Press, New Haven CT.

Greenwood, J., \& Jovanovic, B. (1990). Financial Development, Growth, and the Distribution of Income. Journal of Political Economy, 98, 1076-1107. http://dx.doi.org/10.1086/261720

Greenwood, J., \& Jovanovic, B. (1990). Financial Development, Growth, and the Distribution of Income. Journal of Political Economy, 98, 1076-1107. http://dx.doi.org/10.1086/261720

Greenwood, J., \& Smith, B. (1997).Financial Markets in Development, and the Development of Financial Markets. Journal of Economic Dynamic and Control, 21, 145-181. http://dx.doi.org/10.1016/0165-1889(95)00928-0

Gregory, A. W., \& Hansen, B. E. (1996). Residual-based Tests for Cointegration in Models with Regime Shifts, Journal of Econometrics, 70, 1-26. http://dx.doi.org/10.1016/0304-4076(69)41685-7

Gurley, J., \& Shaw, E. (1967). Financial Structure and Economic Development. Economic Development and Cultural Change, 34, 333-46.

Ireland, P., N. (1994). Money and Growth: An Alternative Approach. American Economic Review, 84, 47-65.

Johansen, S. (1988). Statistical Analysis of Cointegration Vectors. Journal of Economic Dynamic and Control, 12, 231-254. http://dx.doi.org/10.1016/0165-1889(88)90041-3

Jung, W., S. (1986). Financial Development and Economic Growth. International Evidence Economic Development and Cultural Change, 34, 336-346. 
Kargbo, S. M., \& Adamu, P. A. (2009). Financial Development and Economic Growth in Sierra Leone. Journal of Monetary and Economic Integration, 9, 30-61.

Kemal, A. R., Qayyum, A., \& Hanif, M. N. (2007). Financial Development and Economic Growth: Evidence from a Heterogeneous Panel of High Income Countries. The Lahore Journal of Economics, 12, 1-34.

King, R. G., \& Levine, R. (1993). Finance and Growth: Schumpeter Might Be Right. Quarterly Journal of Economics, 108, 717-737. http://dx.doi.org/10.2307/2118406

Kremers, J. J. M., Ericsson, N. R., Juan, J., \& Dolado, J. J. (1992). The Power of Cointegration Tests, Oxford Bulletin of Economics and Statistics, 54, 325-343. http://dx.doi.org/10.1111/j.1468-0084.1992.tb00005.x

Levine, R. (1997). Financial Development and Economic Growth: Views and Agenda. Journal of Economic Literature, 35, 688-726.

Levine, R. (2004). Finance and Growth: Theory and Evidence, NBER Working Paper, No. 10766.

Levine, R., Loayza, N., \& Beck, T. (2000). Finance and the Sources of Growth. Journal of Financial Economics, 58 , 261-300. http://dx.doi.org/10.1016/S0304-405X(00)00072-6

Lucas, R. E. Jr. (1988). On the Mechanics of Economic Development. Journal Monetary Economics, 22, 3-42. http://dx.doi.org/10.1016/0304-3932(88)90168-7

Luintel, K. B., \& Khan, M. (1999). A Quantitative Reassessment of the Finance-Growth Nexus: Evidence from a Multivariate VAR. Journal of Development Economics, 60, 381-405. http://dx.doi.org/10.1016/S0304-3878(99)00045-0

Majid, M. S. (2007). Does Financial Development and Inflation Spur Economic Growth in Thailand? ChulalongkornJournal of Economics, 19, 161-184.

Masih, A. M., \& Masih, R. (2002). Propagative Causal Price Transmission among International Stock Markets: Evidence from the Pre- and Postglobalization Period, Global Finance Journal, 13, 63-91. http://dx.doi.org/10.1016/S1044-0283(02)00039-X

McKinnon, R. (1973). Money and Capital in Economic Development. Brookings Institutions, Washington DC.

Meier, G. M., \& Seers, D. (1984). Pioneers in Development, New York, Oxford University Press.

Mohamad, S. E. (2008). Finance-Growth Nexus In Sudan: Empirical Assessment Based On An Application Of The Autoregressive Distributed Lag (ARDL) Model. Working Paper, No.API/WPS 0803, Arab Planning Institute, Kuwait.

Mosesov, A., \& Sahawneh, N. (2005). UAE: Financial Development and Economic Growth. Skyline Business Journal, 1, 1-11.

Odhiambo, N. M. (2008). Financial Depth, Savings and Economic Growth in Kenya: A Dynamic Causal Linkage. Economic Modeling, 25, 704-713. http://dx.doi.org/10.1016/j.econmod.2007.10.009

Patrick, H. (1966). Financial Development and Economic Growth in Underdeveloped Countries. Economic Development and Cultural Change, 14, 174-189. http://dx.doi.org/10.1086/450153

Pesaran, H. M. (1997). The Role of Economic Theory in Modeling the long-run. Economic Journal, 107, 178-191. http://dx.doi.org/10.1111/1468-0297.00151

Pesaran, H. M., \& Shin, Y. (1995). Autoregressive Distributed Lag Modeling Approach to Cointegration Analysis. Working Paper, No. 9514. Department of Economics, University of Cambridge, DAE.

Pesaran, H. M., \& Shin, Y. (1998). An Autoregressive Distributed Lag Modeling Approach to Cointegration analysis. In: Storm, S. Editor, Econometrics and Economic Theory in the 20th Century, The Ragnar Frisch Centennial Symposium, UK, Cambridge University Press. http://dx.doi.org/10.1017/CCOL0521633230.011

Pesaran, M. H., Shin, Y., \& Smith, R. (1996). Testing for the Existence of a Long-run Relationship, DAE Working Papers, No. 9622, Department of Applied Economics, University of Cambridge. UK.

Pesaran, M. H., Shin, Y., \& Smith, R. (2001). Bounds Testing Approaches to the Analysis of Level Relationships, Journal of Applied Econometrics, 16, 289-326. http://dx.doi.org/10.1002/jae.616

Ram, R. (1999). Financial Development and Economic Growth: Additional Evidence, The Journal of Development Studies, 35, 164-174. http://dx.doi.org/10.1080/00220389908422585

Robinson, J. (1952). The Generalization of the General Theory. In Robinson, The Rate of Interest and Other Essays, (London: Macmillan). 
Rousseau, P. L. (2003). Historical Perspectives on Financial Development and Economic Growth. Federal Reserve Bank of St. Louis Review, 85, 81-106.

Rousseau, P. L., \& Wachtel, P. (2005). Economic Growth and Financial Depth: Is the Relationship Extinct Already. Discussion Paper, No. 2005/10, United Nations University (UNU-WIDER).

Schumpeter, J. A. (1912). The Theory of Economic Development.Harvard University Press, Cambridge, MA.

Seetanah, B. (2008). Financial Development and Economic Growth: An ARDL Approach for the Case of the Small Island State of Mauritius. Applied Economics Letters, 15, 809 - 813.

Shaw, E. S. (1973). Financial Deepening in Economic Development. Oxford University Press, New York.

Stern, N. (1989). The Economics of Development: A Survey. Economic Journal, 99, 597-685. http://dx.doi.org/10.2307/2233764

Tsuru, K. (2000). Finance and Growth: Some Theoretical Considerations and a Review of the Empirical Literature. OECD Economics Department Working Papers, No. 228, OECD Publishing. http://dx.doi.org/10.1787/307832384453

Notes

Note 1. Ram (1999) suggested that the future research on the finance-growth nexus should focus on individual-country studies.

Note 2. Money and quasi money (M2) comprise the sum of currency outside banks, demand deposits other than those of the central government, and the time, savings, and foreign currency deposits of resident sectors other than the central government. This definition of money supply is frequently called M2; it corresponds to lines 34 and 35 in the International Monetary Fund's (IMF) International Financial Statistics (IFS).

Note 3. Domestic credit to private sector refers to financial resources provided to the private sector, such as through loans, purchases of nonequity securities, and trade credits and other accounts receivable, that establish a claim for repayment. For some countries these claims include credit to public enterprises.

Note 4. Levine, Loayza and Beck (2000) also favored this measure of financial development.

Note 5. Al-Malkawi and Abdullah (2011) found negative and significant relationship between government expenditure and inflation and economic growth for a sample of MENA countries including UAE.

Table 1. F-statistics for Testing the Existence of a Long-run Relationship

\begin{tabular}{|l|l|l|}
\hline & Equation & The Calculated F-statistics \\
\hline Model 1 & F(GDP/GOV, TO, INF, DC) & 1.9174 \\
\hline Model 2 & F(GDP/GOV, TO, INF, M2) & $4.812 * *$ \\
\hline
\end{tabular}

Note:The relevant critical value bounds are obtained from Pesaran, Shin and Smith (2001). Table CII (iii) Case III: Unrestricted intercept and unrestricted trend, the number of regressors is 4 . These values are $3.13-4.04$ at $90 \%, 3.41-4.36$ at $95 \%$ and $3.96-4.96$ at $99 \%$ significance level. ** denotes that the F-statistic falls above the $95 \%$ upper bound.

Table 2. Estimated long-run coefficients based on ARDL model selected by AIC $(1,1,0,0,1)$

Dependent variable is LGDP

\begin{tabular}{|l|l|l|}
\hline Regressors & Long-run coefficient & T-Ratio [Prob] \\
\hline Intercept & $34.1962 * * *$ & $12.8690[0.000]$ \\
$\mathrm{t}$ & $0.0747^{* * *}$ & $6.6710[0.000]$ \\
LM2 & $-0.8173^{* * *}$ & $-4.5838[0.000]$ \\
LGOV & $-.81142^{* * *}$ & $-2.4540[0.021]$ \\
LTO & $-0.8891 * * *$ & $-2.2750[0.032]$ \\
INF & $-0.1648^{* * *}$ & $-2.2801[0.031]$ \\
\hline Adj- $R^{2}=0.99$ & & \\
F- statistics $=475.5503[0.000]$ & & \\
D-W $=1.978$ & & \\
LM $=0.00535[0.942]$ & \\
\hline
\end{tabular}

Note: *,** and $* * *$ denote statistical significance at $10 \%, 5 \%$ and $1 \%$ levels, respectively. $-R^{2}$ denotes adjusted R- squared, D-W denotes Durbin-Watson test for autocorrelation, LM denotes Langrange Multiplier. 
Table 3. Granger Causality results based on VECM.

Financial indicator: Money and quasi money as a percentage of GDP (M2).

\begin{tabular}{|c|c|c|c|}
\hline \multirow{2}{*}{ Dependent Variables } & \multicolumn{3}{|c|}{ Independent Variables } \\
\cline { 2 - 4 } & $\Delta \mathrm{GDP}$ & $\Delta \mathrm{M} 2$ & ECM (-1) \\
\hline \multirow{2}{*}{$\Delta \mathrm{GDP}$} & - & $-0.5277^{* * *}$ & $-.2625^{* * *}$ \\
& & {$[-6.3354]$} & {$[-3.2761]$} \\
$\mathrm{N}$ M2 & $-1.1132 * * *$ & - & $-.3759 * * *$ \\
& {$[-6.8587]$} & & {$[-5.3025]$} \\
\hline
\end{tabular}

Note: ${ }^{* *}$ and ${ }^{* * *}$ denote statistical significance at $10 \%, 5 \%$ and $1 \%$ levels, respectively. Figures in squared parentheses represent t-statistics. 